\title{
No Evidence for Binding Between Resistance Gene Product Cf-9 of Tomato and Avirulence Gene Product AVR9 of Cladosporium fulvum
}

\author{
Rianne Luderer, ${ }^{1}$ Susana Rivas, ${ }^{2}$ Thorsten Nürnberger, ${ }^{3}$ Benedetta Mattei, ${ }^{4}$ \\ Henno W. Van den Hooven, ${ }^{5}$ Renier A. L. Van der Hoorn, ${ }^{1}$ Tina Romeis, ${ }^{2}$ Josa-M. Wehrfritz, ${ }^{2}$ \\ Beatrix Blume, ${ }^{3}$ Dirk Nennstiel, ${ }^{3}$ Douwe Zuidema, ${ }^{6}$ Jacques Vervoort, ${ }^{5}$ Giulia De Lorenzo, ${ }^{4}$ \\ Jonathan D. G. Jones, ${ }^{2}$ Pierre J. G. M. De Wit, ${ }^{1}$ and Matthieu H. A. J. Joosten ${ }^{1}$ \\ ${ }^{1}$ Laboratory of Phytopathology, Wageningen University, Binnenhaven 9, 6709 PD Wageningen, The \\ Netherlands; ${ }^{2}$ The Sainsbury Laboratory, John Innes Centre, Colney Lane, Norwich, NR4 7UH, U.K.; \\ ${ }^{3}$ Institute of Plant Biochemistry, Weinberg 3, Halle/Saale, D-06120, Germany; ${ }^{4}$ Dipartimento di Biologia \\ Vegetale, Università di Roma "La Sapienza," Piazzale Aldo Moro 5, 00185, Roma, Italy; ${ }^{5}$ Laboratory of \\ Biochemistry, Wageningen University, Dreijenlaan 3, 6703 HA Wageningen, The Netherlands; \\ ${ }^{6}$ Laboratory of Virology, Wageningen University, Binnenhaven 11, 6709 PD Wageningen, The \\ Netherlands \\ Submitted 16 November 2000; Accepted 13 March 2001.
}

The gene-for-gene model postulates that for every gene determining resistance in the host plant, there is a corresponding gene conditioning avirulence in the pathogen. On the basis of this relationship, products of resistance $(R)$ genes and matching avirulence $(A v r)$ genes are predicted to interact. Here, we report on binding studies between the $R$ gene product $\mathrm{Cf}-9$ of tomato and the $A v r$ gene product AVR9 of the pathogenic fungus Cladosporium fulvum. Because a high-affinity binding site (HABS) for AVR9 is present in tomato lines, with or without the $C f-9$ resistance gene, as well as in other solanaceous plants, the $\mathrm{Cf}-9$ protein was produced in $\mathrm{COS}$ and insect cells in order to perform binding studies in the absence of the HABS. Binding studies with radiolabeled AVR9 were performed with Cf-9-producing COS and insect cells and with membrane preparations of such cells. Furthermore, the $\boldsymbol{C f}$-9 gene was introduced in tobacco, which is known to be able to produce a functional Cf-9 protein. Binding of AVR9 to Cf-9 protein produced in tobacco was studied employing surface plasmon resonance and surface-enhanced laser desorption and ionization. Specific binding between $\mathrm{Cf}-9$ and AVR9 was not

Corresponding author: M. Joosten; Phone: +31 317 483411; Fax: +31 317 483412; E-mail: matthieu.joosten@fyto.dpw.wau.nl

Present address of H. W. Van den Hooven: N. V. Organon, PO Box 20, 5340 BH Oss, The Netherlands.

Present address of J.-M. Wehrfritz: Department of Biochemistry and Molecular Biology, University College London, Darwin Building, Gower Street, London WC1E 6BT, U.K.

Present address of B. Blume: LION Bioscience, Im Neuenheimer Feld 515-517, D-69120 Heidelberg, Germany.

Present address of D. Nennstiel: Martin-Luther-Universität Halle, Institut für Genetik, Weinbergweg 22, D-06120 Halle/Saale, Germany. detected with any of the procedures. The implications of this observation are discussed.

Additional keywords: elicitor, hypersensitive response, LRR, receptor.

Host specificity in plant-pathogen interactions has been described by the gene-for-gene model (Flor 1942), which postulates that for every gene determining resistance in the host, there is a corresponding gene conditioning avirulence in the pathogen. On the basis of this relationship, products of resistance $(R)$ genes and matching avirulence $(A v r)$ genes are predicted to interact, resulting in an incompatible interaction (Keen 1990). To date, a variety of $R$ and Avr genes have been cloned (Jones and Jones 1996; Laugé and De Wit 1998; Van der Biezen and Jones 1998).

Until now, only for two R proteins, Pto from tomato and Pita from rice, physical interaction with a pathogen-derived ligand, AvrPto and AVR-Pi-ta, respectively, has been reported (Jia et al. 2000; Scofield et al. 1996; Tang et al. 1996). Pto is a protein kinase, of which kinase activity is required for the activation of a resistance response (Sessa et al. 1998). The Pita resistance gene encodes a predicted cytoplasmic protein containing a nucleotide binding site and a leucine rich carboxyl terminus (Jia et al. 2000). The number of $R$ genes for which the matching Avr gene has been cloned is increasing (Laugé and De Wit 1998). This allows for more extensive studies of the mechanisms by which plant $R$ gene and corresponding pathogen-derived avirulence gene products interact and subsequently determine the outcome of the plantpathogen interaction.

The interaction between tomato and the strictly apoplastic, biotrophic pathogen Cladosporium fulvum complies with the gene-for-gene model. From tomato, several $C f$ genes mediat- 
ing resistance to specific races of $C$. fulvum have been cloned (Joosten and De Wit 1999). All $C f$ genes are predicted to encode extracytoplasmic, membrane-anchored glycoproteins that contain many leucine-rich repeats (LRRs) (Fig. 1). LRRs are thought to be involved in protein-protein interactions (Kobe and Deisenhofer 1994). The N-terminal domains, which are highly variable, are thought to play a role in recognitional specificity, whereas the C-terminal parts of the LRRs of Cf proteins show a remarkable homology (Dixon et al. 1996). For $C f-4$ and $C f-9$, the avirulence genes encoding the corresponding race-specific elicitor of C. fulvum, Avr4 and Avr9, respectively, have been cloned (Joosten et al. 1994; Van den Ackerveken et al. 1992; Van Kan et al. 1991). Recognition of these elicitors by tomato genotypes carrying the matching resistance gene results in a typical hypersensitive response (HR) (Joosten et al. 1994; Van den Ackerveken et al. 1992).

Upon colonization of the intercellular spaces of tomato leaves, C. fulvum secretes elicitors into the apoplast (Joosten and De Wit 1999). The apoplastic localization of the various elicitors, together with the localization of the LRR region of the $\mathrm{Cf}$ proteins on the outer surface of the plasma-membrane of the host cells (Piedras et al. 2000), is consistent with the hypothesis that a direct interaction occurs between $C$. fulvum-derived elicitors and the matching $\mathrm{Cf}$ proteins. Although the $\mathrm{C}$-terminal dilysine motif of the Cf-9 protein suggests that Cf-9 is localized in the endoplasmic reticulum (ER) (Benghezal et al. 2000), this motif is not essential for Cf-9 function (Van der Hoorn et al. 2001), suggesting that functional Cf-9 protein resides in the plasma membrane, as shown by Piedras et al. (2000).

The availability of near-isogenic lines (NILs) of tomato containing particular $C f$ genes and of matching elicitor proteins allows for detailed studies on mechanisms of elicitor perception by a resistant host. Binding studies with radiolabeled AVR9 elicitor protein showed the presence of a highaffinity binding site (HABS) for this elicitor in plasma membranes isolated from leaves of NILs of tomato, either with or without the $C f-9$ resistance gene (Kooman-Gersmann et al. 1996). Furthermore, other solanaceous plants were found to contain such a binding site, indicating that the Cf-9 protein itself is not the HABS (Kooman-Gersmann et al. 1996).

Direct interaction between AVR9 and Cf-9 employing the yeast two-hybrid system could not be detected (F. Laurent and G. Honée, unpublished data). This system, however, is not entirely suitable to study interactions between such proteins. In order to perform binding studies with membrane-localized Cf-9 protein in the absence of the HABS, the Cf-9 protein was produced in $\mathrm{COS}$ and insect cells. Furthermore, the $C f-9$ gene was introduced in tobacco, which is known to produce functional Cf-9 protein because the injection of AVR9 into Cf-9transgenic tobacco results in HR, which is visible as necrosis

\begin{tabular}{|c|c|c|}
\hline SP & LRRs & $\mathrm{TM}$ \\
\hline \begin{tabular}{|l|l|}
$A$ & $B$ \\
\end{tabular} & C & DEF \\
\hline
\end{tabular}

Fig. 1. Schematic representation of the Cf-9 protein, which can be divided into seven domains: A, the predicted signal peptide (SP); B, the predicted amino terminal domain of the mature protein; $\mathrm{C}$, the leucinerich repeats domain (LRRs); D, a connecting domain; E, an acidic domain; F, the transmembrane domain (TM); G, a basic domain. Domains E-G anchor and orient Cf-9 in the plasma membrane in such a way that domains B-E are extracytoplasmic and domain $\mathrm{G}$ forms a cytoplasmic tail (Jones and Jones 1996; Piedras et al. 2000).
(Hammond-Kosack et al. 1998). Here, we report on binding studies between AVR9 and Cf-9 produced in these three different expression systems. Binding studies with ${ }^{125}$ I-AVR9 and Cf- 9 produced by COS or insect cells were performed following the methods described by Kooman-Gersmann et al. (1996). Binding of AVR9 to Cf-9 protein produced in tobacco was studied employing surface plasmon resonance (SPR), with BIAcore technology (Fivash et al. 1998), and surfaceenhanced laser desorption and ionization (SELDI) (Hutchens and Yip 1993). Specific binding between Cf-9 and AVR9 was not detected with any of the procedures. The implications of this finding are discussed.

\section{RESULTS}

\section{Production of Cf-9 protein in COS cells.}

COS cells were cotransfected with $C f$ - 9 fused to a mammalian signal peptide sequence and the gene encoding green fluorescent protein (GFP) (Sheen et al. 1995). GFP expression was used to monitor the efficiency of transfection. Only those cell lines in which significant expression of GFP was observed were used in AVR9-binding assays. Immunolocalization of Cf-9 revealed that the protein is predominantly present in the plasma membrane of COS cells (Fig. 2), whereas GFP accumulated in the cytoplasm and nucleus (not shown). The observation that the Cf- 9 protein is present at the expected location indicates that the mammalian signal peptide directs the protein to the proper processing route, allowing posttranslational modifications. No cross reactivity of Cf-9 antibodies was observed in untransfected COS cells (results not shown).

\section{Binding studies with Cf-9 protein from COS cells.}

Ligand binding assays with ${ }^{125}$ I-AVR9 were performed with intact transgenic, Cf-9-producing COS cells and microsomal
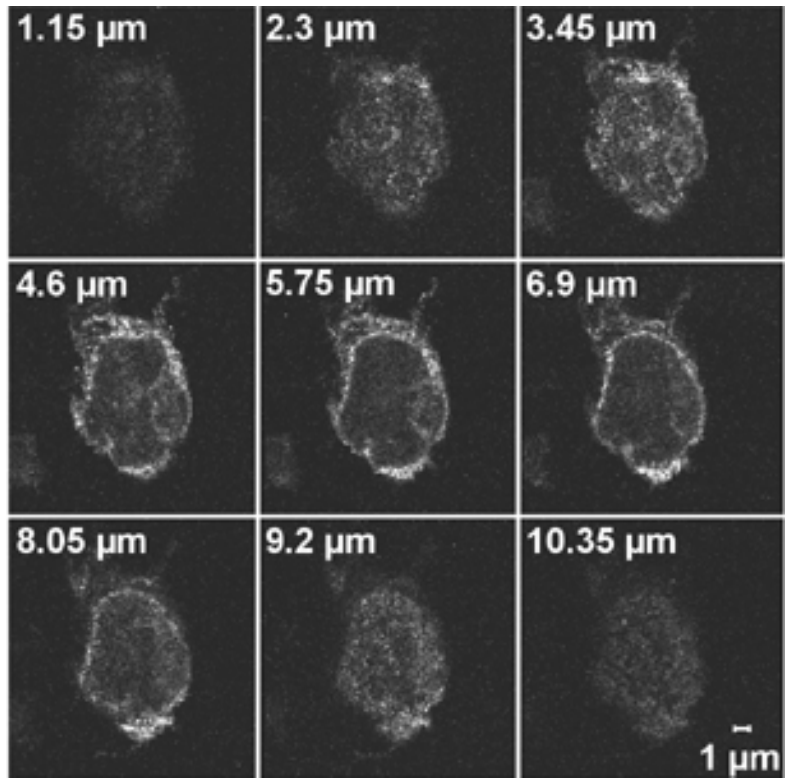

Fig. 2. Immunocytochemical visualization of Cf-9 in COS cells, which were fixed 3 days after transfection with a $C f$-9-containing vector. Cf- 9 protein was visualized with Cf- 9 antibodies combined with a secondary antibody coupled to the fluorescent dye Alexa 546. Consecutive sections of the cells are shown. The distances between dissection levels are indicated in micrometers. 
membrane preparations from such cells. Nonspecific binding was determined in the presence of an excess of unlabeled AVR9. No significant difference between total and nonspecific binding of ${ }^{125} \mathrm{I}$-AVR9 to Cf-9-producing COS cells or to derived microsomal membrane preparations was observed (Fig. 3). Similar results were obtained with nontransgenic COS cells (results not shown). Thus, no specific binding could be detected under the conditions applied. Similar binding studies with the human melanocyte stimulating hormone (MSH) receptor and ${ }^{125}$ I-labeled $\alpha$-MSH showed that such binding studies employing COS cells are adequate for detecting receptor-ligand interactions, with binding affinities that are similar to the affinity expected for the binding of AVR9 to Cf-9 (data not shown). Specific binding is not likely to be masked by the amount of nonspecific binding because nonspecific binding only reflects approximately $7 \%$ of the total radioligand used for binding studies with membrane preparations.

In an attempt to identify appropriate conditions for radioligand binding, the experimental conditions of the AVR9 binding assay were changed sequentially. ${ }^{125}$ I-AVR9 binding was not affected by alteration of the incubation temperature from $37^{\circ} \mathrm{C}$ to room temperature or $0^{\circ} \mathrm{C}$ (results not shown). Similarly, variation of the $\mathrm{pH}$ of the ligand binding buffer $(\mathrm{pH} 4.5$, 5.5, 6.5, or 7.5) did not result in detectable, specific AVR9 binding. The addition of $\mathrm{NaCl}, \mathrm{KCl}$, or $\mathrm{KI}$ (at $100 \mathrm{mM}$ each) did not reduce nonspecific binding. Also, solubilization of microsomal membranes, either by $1 \%$ Triton X-100 or $1 \%$ octylglucoside, which is frequently used to solubilize plasma membrane receptors, did not result in specific binding of ${ }^{125} \mathrm{I}$ AVR9 (results not shown). Thus, none of the various conditions applied resulted in detectable, specific binding of ${ }^{125} \mathrm{I}-$ AVR9 to the Cf-9 protein produced by COS cells.

\section{Production of $\mathbf{C f}-9$ protein in insect cells.}

In addition to expression in COS cells, $C f-9$ was expressed with the baculovirus expression system. Two different recombinant baculovirus constructs were employed for production of the Cf-9 protein. One recombinant virus contained the

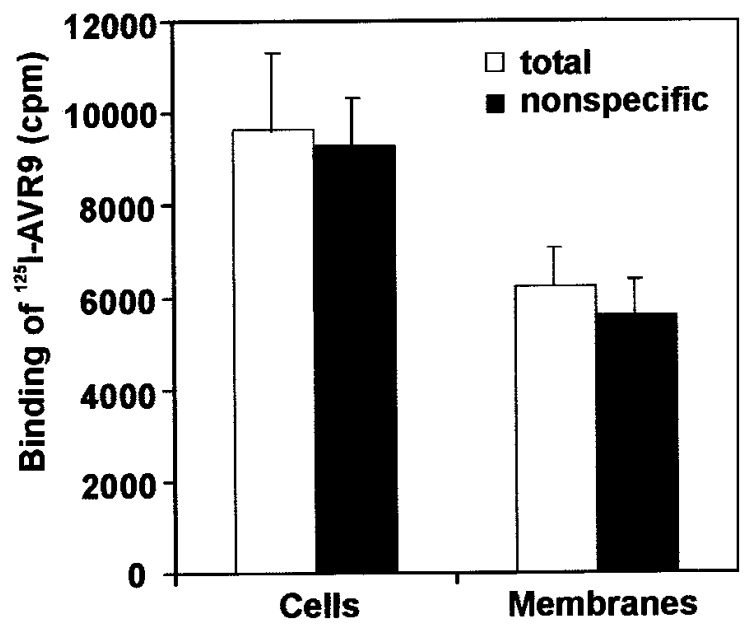

Fig. 3. Binding of ${ }^{125} \mathrm{I}$-AVR 9 to $C f$-9-expressing COS cells and microsomal membranes of these cells. Total binding (white columns) and nonspecific binding (black columns) are indicated in counts per minute $(\mathrm{cpm})$ for cells $(n=12)$ and microsomal membranes $(n=3)$. complete $C f-9$ cDNA ( $C f-9)$, including the native signal sequence, whereas the other encoded the predicted extracellular part of Cf-9 (domain A to halfway through domain E; Fig. 1) containing a C-terminal $\mathrm{His}^{6}$-tag $\left(C f-9^{\mathrm{H}}\right)$.

Production of Cf- 9 by baculovirus-infected insect cells was confirmed by immunoblot analysis. Different forms of Cf-9 protein are present in insect cells. Predominant forms range from approximately 84 to $125 \mathrm{kDa}$ for complete Cf-9 (Fig. 4). Compared with $C f-9^{\mathrm{H}}$, the lower mobility of the proteins produced by insect cells infected by baculovirus containing $C f-9$ is consistent with the size difference of the corresponding open reading frames. The largest form of Cf- $9^{\mathrm{H}}$ protein detected in cells infected by baculovirus expressing $C f-9^{\mathrm{H}}$ is approximately $116 \mathrm{kDa}$ in molecular weight. This form also was detected in culture medium, whereas no Cf- 9 was detected in culture medium of cells infected by baculovirus expressing the complete $C f-9$ cDNA (Fig. 4, see arrow). This suggests that the native, N-terminal signal sequence for extracellular targeting of Cf- 9 is recognized in insect cells and that the membrane anchor of the complete Cf- 9 protein comprising domains $\mathrm{E}, \mathrm{F}$, and $\mathrm{G}$ prevents it from being secreted.

The amount of extracellular $\mathrm{Cf}-\mathrm{9}^{\mathrm{H}}$ produced, however, was too low to purify the protein from the culture medium. Therefore, a procedure was initiated to purify $\mathrm{Cf}-9$ proteins from insect cell extracts. As the various forms of Cf-9 and Cf- $9^{\mathrm{H}}$ turned out to be insoluble under native conditions (results not shown), affinity purification of $\mathrm{Cf}-9^{\mathrm{H}}$ was performed under denaturing conditions (see below). Purification of $\mathrm{Cf}-9^{\mathrm{H}}$ under denaturing conditions yielded three forms that were approximately 75,80 , and $116 \mathrm{kDa}$, which all cross reacted with antibodies raised against the Cf-9 protein (Fig. 5). As these three forms were purified employing their $\mathrm{C}$-terminal $\mathrm{His}_{6}$-tag, they all derived from a full-length translation product. The $116-\mathrm{kDa}$ form of $\mathrm{Cf}-9^{\mathrm{H}}$ migrated as a more diffuse band than did the 75- and $80-\mathrm{kDa}$ forms. Because the Cf-9 protein contains 22 potential N-glycosylation sites (Jones et al. 1994), it was an-

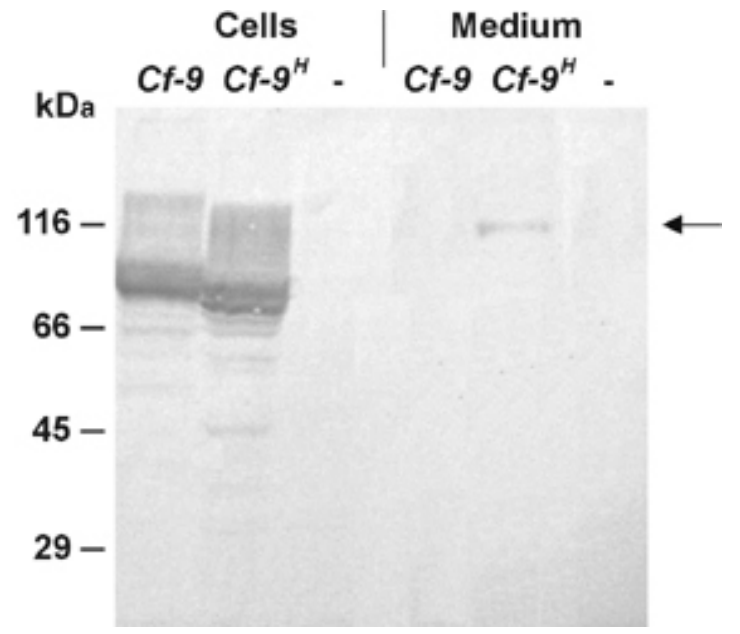

Fig. 4. Western blot analysis of $\mathrm{Cf}-9$ and $\mathrm{Cf}-9^{\mathrm{H}}$ proteins produced with the baculovirus expression system. Insect cells were infected by baculovirus containing $C f-9$ or $C f-9^{\mathrm{H}}$ or by baculovirus without an insert (-) and cultured in SF900 II medium. Proteins present in cell lysates and medium were separated by sodium dodecyl sulfate-polyacrylamide gel electrophoresis, followed by immunodetection with the use of Cf-9 antibodies. Arrow indicates the $116-\mathrm{kDa}$ form of $\mathrm{Cf}-9^{\mathrm{H}}$. Molecular weight marker positions are indicated on the left. 
ticipated that this diffuse band represents a glycosylated form of Cf- $9^{\mathrm{H}}$. Cells that were incubated in the presence of tunicamycin, an inhibitor of $\mathrm{N}$-glycosylation, did not produce the $116-\mathrm{kDa}$ form, whereas the $75-$ and $80-\mathrm{kDa}$ forms were still produced (results not shown), indicating that the $116-\mathrm{kDa}$ band indeed represents a glycosylated form of Cf- $9^{\mathrm{H}}$. Similar results were obtained when insect cells infected with baculovirus expressing the complete $C f-9$ cDNA were incubated with tunicamycin. These data also indicate that approximately $41 \mathrm{kDa}$ of the mass of the Cf-9 protein produced in insect cells represents $\mathrm{N}$-glycosylation, which contributes approximately $55 \mathrm{kDa}$ to the mass of the $\mathrm{Cf}-9$ protein produced in tobacco (Piedras et al. 2000). This difference is probably the result of the differences between the glycosylation in insects and plants (King and Possee 1992). Upon processing Cf- $9^{\mathrm{H}}$, removal of the signal peptide occurred because $\mathrm{N}$-terminal sequencing of the $116-\mathrm{kDa}$ form of $\mathrm{Cf}-9^{\mathrm{H}}$ revealed that the signal peptide had been cleaved off at the position predicted by Jones et al. (1994). N-terminal sequencing of the 80- and $75-\mathrm{kDa}$ forms of $\mathrm{Cf}-9^{\mathrm{H}}$ did not result in a clear amino acid sequence. We expect that these forms represent nonglycosylated $\mathrm{Cf}-9^{\mathrm{H}}$ protein, either with $(80 \mathrm{kDa})$ or without $(75 \mathrm{kDa})$ signal peptide, because the estimated masses of these forms are close to the calculated masses of 88.4 and $85.9 \mathrm{kDa}$, respectively. These results indicate that at least part of the fulllength Cf-9 protein produced in insect cells is directed to the proper processing route, allowing glycosylation and removal of the signal sequence.

\section{Binding studies with $\mathrm{Cf}-9$ proteins produced by insect cells.}

$\mathrm{Cf}-\mathrm{9}^{\mathrm{H}}$ protein was purified under denaturing conditions. Because these conditions are expected to render the protein unsuitable for binding studies, binding assays were performed with whole insect cells, producing the complete Cf-9 protein containing the membrane anchor, and with membrane-

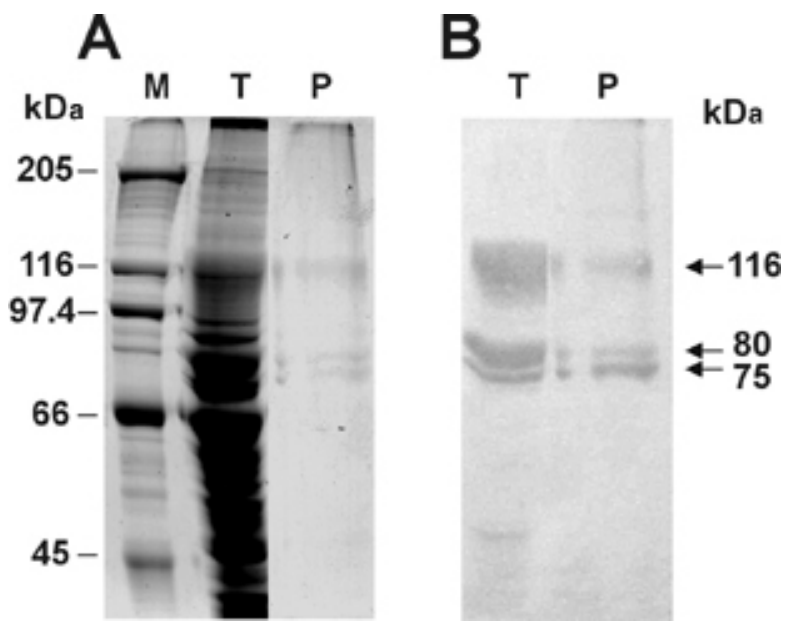

Fig. 5. Affinity purification of $\mathrm{Cf}-9^{\mathrm{H}}$ from insect cells under denaturing conditions. Cf $-9^{\mathrm{H}}$ was purified from total insect cell proteins (T). The purified fraction $(\mathrm{P})$ contains three forms of $\mathrm{Cf}-9^{\mathrm{H}}$ of approximately 75 , 80 , and $116 \mathrm{kDa}$ (arrows). Proteins that were present in complete cell lysates and purified fractions were analyzed by sodium dodecyl sulfatepolyacrylamide gel electrophoresis, followed by $\mathbf{A}$, Coomassie staining or $\mathbf{B}$, immunodetection with the use of Cf- 9 antibodies. Marker molecular weight is indicated on the left. enriched fractions of such cells. Binding assays were performed in a similar way, as described for binding studies with microsomal fractions of plant (Kooman-Gersmann et al. 1996) and COS cells (this article). Sodium dodecyl sulfatepolyacrylamide gel electrophoresis (SDS-PAGE) confirmed that the membrane-enriched fractions of Cf-9-producing insect cells also were enriched for all forms of Cf-9 (results not shown). This enrichment, however, partly is the result of the presence of insoluble Cf-9 protein that ends up in the final pellet, representing the membrane-enriched fraction. Insect cells infected by baculovirus without insert and derived membrane-enriched fractions, were used as a control. During all binding studies with Cf-9 produced in insect cells, microsomal fractions of MM-Cf9 tomato leaves were included as a positive control for the experimental procedures. When standard binding conditions were used, no specific binding of ${ }^{125} \mathrm{I}-$ AVR9 to Cf-9-producing insect cells or derived membraneenriched fractions was observed (data not shown). Binding of AVR9 to the HABS present in the microsomal fractions of tomato leaves was always detected, whereas the amount of glycosylated Cf-9 from insect cells present in binding assays is estimated to be at least 10,000-fold (membrane-enriched fractions) or 1,000-fold (cells) higher than the amount of HABS present in the microsomal fractions of tomato leaves.

In an attempt to optimize binding conditions, some parameters of the binding buffer were varied. Binding studies with membrane-enriched fractions were performed at different $\mathrm{pH}$ valves ( $\mathrm{pH} \mathrm{4,} \mathrm{5,} \mathrm{6,} \mathrm{7,} \mathrm{8,} \mathrm{and} \mathrm{9)} \mathrm{and} \mathrm{salt} \mathrm{concentrations}(0,100$, and $500 \mathrm{mM} \mathrm{NaCl}$ ). None of the various conditions, however, resulted in the detection of specific binding of ${ }^{125}$ I-AVR9 to membrane-enriched fractions (data not shown).

As an alternative to standard binding studies, a native dot blot was made of Cf-9-producing insect cells. Mock-infected insect cells and a microsomal fraction, including the HABS, isolated from leaflets of MM-Cf9 plants, were spotted as controls. The amount of glycosylated Cf-9 present in the spots of Cf-9 producing insect cells is estimated to be at least 1,000fold higher than the amount of HABS present in the spots of the microsomal fraction of MM-Cf9 plants. The Cf-9 protein in insect cells was detected readily by Cf- 9 antibodies, whereas the amount of $\mathrm{Cf}$ proteins in the microsomal fraction of MM-Cf9 plants was too low to obtain a visible signal (Fig. 6 , upper panel). Binding of ${ }^{125}$ I-AVR9 to the spotted Cf-9-

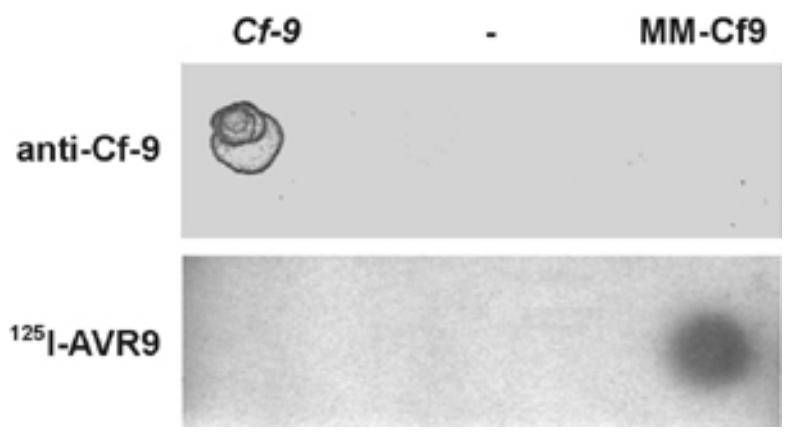

Fig. 6. Binding of ${ }^{125}$ I-AVR9 to a native dot blot spotted with Cf-9producing insect cells. Insect cells were either infected by baculovirus containing $C f-9(C f-9)$ or mock infected (-) and spotted onto nitrocellulose. As a positive control, a microsomal fraction of MM-Cf9 tomato plants was spotted (MM-Cf9). Similar blots were treated with Cf-9 antibodies (upper panel) or ${ }^{125}$ I-AVR9 (lower panel). 
producing insect cells, however, was not observed, whereas the microsomal fraction of MM-Cf9 plants present on the blot did bind ${ }^{125}$ I-AVR9 (Fig. 6, lower panel). Similar experiments were performed with blots spotted with culture medium of insect cells expressing $C f-9^{\mathrm{H}}$. Again, no specific binding of ${ }^{125}$ I-AVR9 was detected (data not shown).

\section{Production of Cf-9 protein in tobacco.}

Because no specific binding of AVR9 to Cf-9 protein produced by COS or insect cells was observed, binding studies were performed with $\mathrm{Cf}-9$ protein produced in tobacco. Transformation of tobacco with $c-m y c: C f-9$ resulted in a line, designated 9161, showing HR upon injection of AVR9 (Piedras et al. 2000). The c-myc:Cf-9 protein was localized in the plasma membrane (Piedras et al. 2000) and could be solubilized from a microsomal fraction isolated from leaves of the 9161 line with $0.1 \%$ Nonidet P-40 (Fig. 7, lane 1). Nonidet P-40 commonly is used for the native solubilization of membrane proteins (Hjelmeland 1990). Nonidet P-40, however, reduces the binding of AVR9 to the HABS detected in tobacco by Kooman-Gersmann et al. (1996) (R. A. L. Van der Hoorn, unpublished results), resulting in reduced interference of the HABS in binding studies between AVR9 and Cf-9. The solubilized c-myc:Cf-9 protein from tobacco was used in in vitro binding experiments employing SPR and SELDI techniques.

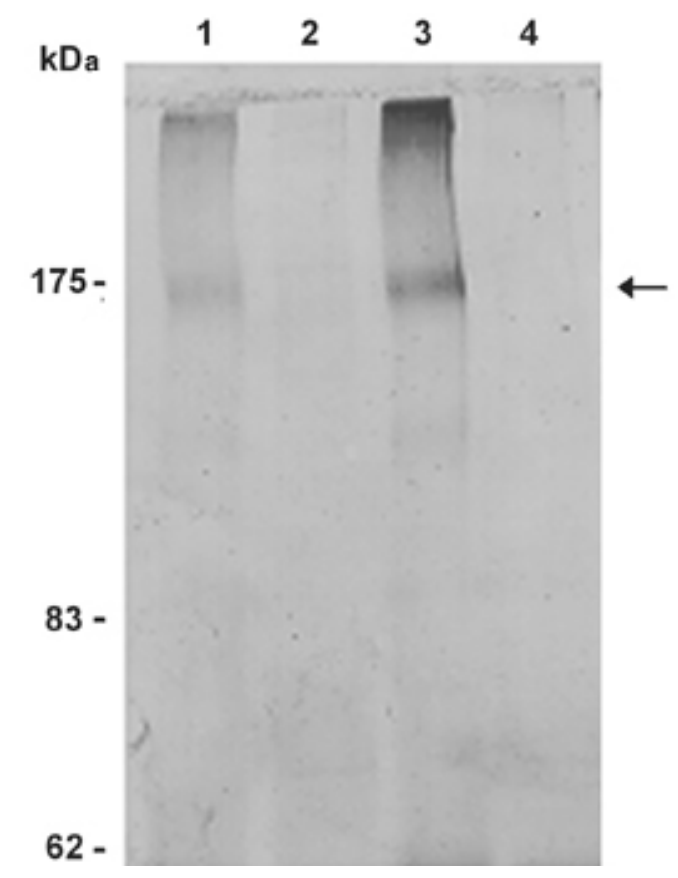

Fig. 7. Specific immunoprecipitation of c-myc:Cf-9 protein produced in tobacco by c-myc antibodies. Immunoprecipitation was carried out with microsomal preparations of leaves from $c$-myc: $C f$-9-transgenic tobacco (line 9161) and c-myc monoclonal antibodies, as described in text. The immunoprecipitated proteins were separated by sodium dodecyl sulfatepolyacrylamide gel electrophoresis and detected with the use of c-myc polyclonal antibodies. Lane 1, total microsomal fraction; lane 2, material bound nonspecifically to the protein $\mathrm{G}$ beads during the preclearing step; lane 3, material immunoprecipitated by the c-myc antibody; lane 4, material immunoprecipitated by unrelated hemagglutinin antibodies. Arrow indicates the position of the c-myc:Cf-9 protein. Molecular weight marker positions are indicated on the left.

\section{SPR experiments with c-myc:Cf-9 protein produced in tobacco.}

SPR analysis was carried out with biotinylated AVR9, which has been demonstrated to have necrosis-inducing activity (Van den Hooven et al. 1999), immobilized onto the chips. Total solubilized microsomal proteins from the 9161 line or untransformed Nicotiana tabacum cv. Petite Havana plants (PH.4) were diluted in $20 \mathrm{mM}$ sodium phosphate, $\mathrm{pH}$ 6.0, and injected into the flow cell. The resonance signals at the steady state $\left(\mathrm{R}_{\mathrm{eq}}\right)$ that were obtained with both protein preparations were similar at comparable total solubilized microsomal protein concentrations (Fig. 8A and C). When $0.5 \mu \mathrm{g}$ of R8K AVR9 (an AVR9 mutant showing increased necrosis-inducing activity) (Kooman-Gersmann et al. 1997) was injected with the membrane protein samples, a similar decrease in $\mathrm{R}_{\mathrm{eq}}$ values was observed for proteins from the 9161 line (Fig. 8B) and PH.4 (Fig. 8D). These results indicate that the observed binding of Cf-9-containing membrane proteins to immobilized AVR9 does not reflect specific binding of Cf-9 protein but probably represents some residual binding of the HABS, in addition to nonspecific binding. Also, when a $\mathrm{pH}$ of 7.3 was applied, either with or without $100 \mathrm{mM} \mathrm{NaCl}$, no specific binding of Cf-9 proteins to the AVR9-coated chip could be detected. The observed residual binding of the HABS (Fig. 8B and D) does indicate that the experimental setup of the SPR experiments is adequate to detect binding to the immobilized AVR9. Thus, these experiments did not provide any evidence for specific binding of Cf-9 to the immobilized AVR9 peptide.

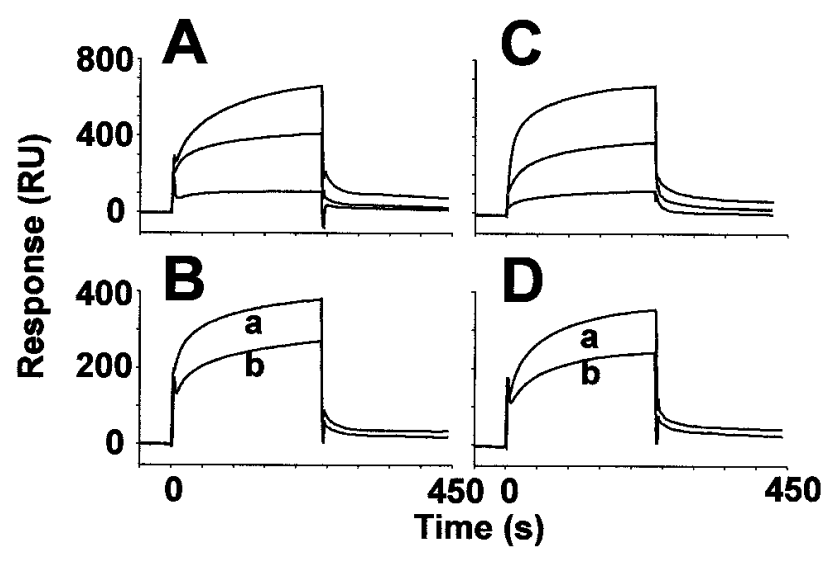

Fig. 8. Sensorgrams of the interaction between immobilized, biotinylated AVR9 and solubilized microsomal proteins from tobacco. Samples injected into the flow cell were: A, solubilized membrane proteins from $c$-myc:Cf-9-transgenic tobacco line 9161; increasing concentrations of membrane protein samples were used (from bottom to top curve: 30,100 , and $500 \mathrm{ng}$ of total proteins per $\mu \mathrm{l}$ ); $\mathbf{B}$, same sample as in $\mathbf{A}$, injected at $100 \mathrm{ng} / \mu \mathrm{l}$ (a) and $100 \mathrm{ng} / \mu \mathrm{l}$ in the presence of the competing R8K mutant of AVR9 (b); $\mathbf{C}$, solubilized membrane proteins from untransformed PH.4 plants (bottom to top curve: 30, 100, and 500 $\mathrm{ng} / \mu \mathrm{l}$ ); D, same sample as in $\mathbf{C}$, injected at $100 \mathrm{ng} / \mu \mathrm{l}$ (a) and $100 \mathrm{ng} / \mu \mathrm{l}$ in the presence of the competing R8K mutant of AVR9 (b). Response expressed in resonance units (RU) is reported as the difference between the signal obtained from the flow cell with immobilized AVR9 and a second flow cell without peptide. The initial baseline corresponds to the buffer flow over the AVR9 surface. An increase in RU occurs during the association phase upon sample injection. The maximum resonance signal reached during sample injection reflects the steady state, whereas the decrease in RU that occurs at the end of the injection, when sample is replaced by buffer, corresponds to the dissociation phase. 


\section{SELDI experiments with Cf-9 protein produced in tobacco.}

SELDI also was used to study whether there is interaction between AVR9 and Cf-9. This technique allows determination of the mass of peptides that bind to proteins, which are covalently coupled to a chip, by measuring their time of flight with a mass spectrometer after laser irradiation.

Proteins solubilized from microsomal fractions isolated from leaves of line 9161 and the untransformed line PH.4 were immunoprecipitated with c-myc monoclonal antibodies. Cf-9 was present in the precipitate obtained from the 9161 microsomal preparation (Fig. 7, lane 3). The specificity of the antibody was confirmed by the absence of immunoprecipitate when extracts from untransformed PH.4 plants (not shown) were used. No immunoprecipitated proteins were detected after the preclearing step with only protein $\mathrm{G}$ (Fig. 7, lane 2), and Cf-9 was not precipitated by unrelated hemagglutinin antibodies (Fig. 7, lane 4). Thus, c-myc:Cf-9 can be purified from a microsomal fraction of line 9161 by solubilization, followed by immunoprecipitation. The results were identical when cell cultures rather than leaves of line 9161 were used to obtain microsomal fractions (data not shown).

For SELDI, immunocomplexes obtained either from cell cultures of line 9161 or PH.4 were coupled to a protein Gcoated chip. About twice as much binding of AVR9 was observed to c-myc:Cf-9-containing extracts than to extracts from PH.4 cell cultures (results not shown). Protein content and composition of the immunocomplexes originating from the cell cultures of line 9161 and PH.4, however, are probably very different. Therefore, competition experiments were carried out to further characterize the significance of the binding of AVR9 to c-myc:Cf-9-containing extracts.

Competition experiments were performed with mutants of AVR9 having higher (R8K), lower (F10A), or no necrosisinducing activity (F21A) (Kooman-Gersmann et al. 1997). The necrosis-inducing activity of these AVR9 mutants has been shown to correlate with their affinity for the HABS (KoomanGersmann et al. 1998). The SELDI technique is sufficiently sensitive to distinguish between the molecular mass of AVR9 and the mutant peptides (results not shown). Competition experiments were performed in such a way that initially, AVR9 was bound onto the immunocomplex-treated chip and, after washing, the three different AVR9 mutants were added as competitors. There was no correlation between the ability of the AVR9 mutants to compete with AVR9 binding and their necrosis-inducing activity (Fig. 9). Similar results were obtained with the c-myc:Cf- 9 protein isolated from $C f$-9-transgenic tobacco leaves instead of from cell cultures. These results indicate that the apparent enhanced binding of AVR9 to immunoprecipitated Cf-9 is unlikely to reflect specific AVR9 binding because it cannot be competed specifically. It has to be taken into account, however, that although there is a correlation between the necrosis-inducing activity of AVR9 mutants, with their affinity for the HABS, a similar correlation does not necessarily exist with their potential affinity for Cf-9.

\section{DISCUSSION}

\section{No detected binding of AVR9 to Cf-9.}

We studied whether binding of race-specific elicitor AVR9 of $C$. fulvum to Cf- 9 , the product of resistance gene $C f-9$ of tomato, occurs. Cf-9 protein was produced in different heterologous systems, and various experimental procedures were employed to reveal whether the Cf-9 protein has binding affinity for the AVR9 elicitor. With all of the approaches we followed, however, no specific binding of AVR9 to Cf-9 was observed. The functionality of the heterologously produced Cf-9 protein and the methods used to study the potential interaction are evaluated and discussed.

Cf-9 protein was produced in COS cells, insect cells, and tobacco plants as well as in cell cultures derived from these plants. The COS cell and baculovirus expression systems employing insect cells have previously been shown to be suitable for expression of various functional receptor proteins (Greenfield et al. 1988; Kieffer et al. 1992; Mathews and Vale 1991; Webb et al. 1989). Although there is no proof that Cf-9 produced in these systems is functional, the Cf- 9 protein produced in COS cells was present in the plasma membrane (Fig. 2), whereas at least part of the Cf-9 protein produced in insect cells is directed to the proper processing route, allowing glycosylation of the protein and removal of the signal sequence. The transgenic tobacco line was shown to produce functional c-myc:Cf-9 protein because injection of the AVR9 peptide in these plants resulted in typical necrosis (Piedras et al. 2000).

Binding studies with Cf-9 produced in COS and insect cells were performed according to Kooman-Gersmann et al. (1996). They used ${ }^{125}$ I-AVR9 and microsomal fractions or plasma membranes of leaves to identify a HABS for AVR9 in tomato and other solanaceous plants. Considering the high amounts of heterologously produced Cf-9 protein used in the binding studies described in this article and the broad range of conditions that were tested to detect specific binding between AVR9 and Cf-9, we expected to detect specific binding if the Cf-9 protein and the AVR9 elicitor do, in fact, interact.

AVR9 binding to myc-tagged Cf-9 produced in tobacco was studied employing SPR, with BIAcore technology, and SELDI. The c-myc:Cf-9 protein was solubilized from microsomal fractions with Nonidet P-40. Although Nonidet P-40 commonly is used for the native solubilization of membrane proteins (Hjelmeland 1990), it cannot be excluded that Nonidet P-40 interferes with the potential binding between AVR9 and Cf-9. SPR is an excellent method to study qualitative aspects of protein-protein interactions (Fivash et al. 1998) and has been shown to be a functional tool for studies on LRR proteins (Leckie et al. 1999). Therefore, a comparison between microsomal protein preparations of tobacco, with or without Cf-9, could reveal binding between AVR9 and Cf-9. No difference in AVR9 binding was observed between microsomal protein fractions, however, whether they contained Cf-9 or not (Fig. 8).

SELDI ProteinChip technology (Hutchens and Yip 1993) is a tool to study macromolecular interactions. Several researchers have reported on the successful use of SELDI to study protein-protein interactions (Davies et al. 1999; Kuwata et al. 1998), indicating that the use of SELDI to identify specific binding between AVR9 and Cf-9 is feasible. No correlation was found, however, between the necrosis-inducing activity of AVR9 mutants and their ability to compete with AVR9 binding (Fig. 9).

It could be argued that we failed to detect binding between AVR9 and Cf-9 because we did not identify the right experimental conditions. We consider it likely, however, that the 
lack of detection of specific binding of AVR9 to Cf-9, following many different approaches, reflects the absence of interaction between these proteins.

\section{Perception of AVR9 by Cf-9.}

Our results indicate that AVR9 does not bind directly to the Cf-9 protein, implying that at least a third partner is required for perception of AVR9 by Cf-9. Introduction of the $C f-9$ gene, however, has been shown to be essential and sufficient to confer the ability to respond to AVR9 to tomato, tobacco, potato, and petunia (Hammond-Kosack et al. 1998; Van der Hoorn et al. 2000), indicating that the proposed third interacting partner is already present in these species. In the same species, a HABS for AVR9 was detected in plasma membranes (Kooman-Gersmann et al. 1996). Furthermore, the necrosis-inducing activity of AVR9 mutants was shown to be correlated with their affinity for the HABS (KoomanGersmann et al. 1998). Therefore, the HABS is a good candidate for the third interacting partner involved in the perception of AVR9 by Cf-9 (Joosten and De Wit 1999; KoomanGersmann et al. 1998). Whether the HABS is actually involved in the perception of AVR9 in combination with Cf-9 has to be proven. Currently, efforts are being made to purify the HABS. Hopefully, this will lead to further insights into the nature of the HABS and the mechanism by which perception of AVR9 by Cf-9 takes place.

If a third interacting partner is involved in the perception of AVR9 by Cf-9, this implies that the simplest interpretation of Flor's gene-for-gene concept, direct interaction of a pathogenderived elicitor with a matching resistance gene product (Flor 1942; Keen 1990), does not hold for the Avr9-Cf-9 gene pair. Recognition mediated by a third interacting partner was suggested before for the recognition of AvrPto of Pseudomonas syringae by tomato (Van der Biezen and Jones 1998), AvrRpt2 of $P$. syringae by Arabidopsis (Leister and Katagiri 2000), and turnip crinkle virus capsid protein by Arabidopsis (Ren et al. 2000). Also, in other host-pathogen interactions that comply with the gene-for-gene concept, perception of a pathogenderived elicitor by the resistance gene product might depend upon a third interacting partner. Moreover, the nature of this third partner might vary among different pathosystems. Therefore, we argue that although the genetics of the gene-for-gene concept suggest a simple direct receptor-ligand interaction, the actual biochemical mechanism of elicitor perception might be more complex than anticipated.

\section{MATERIALS AND METHODS}

\section{Expression of $\mathrm{Cf}-9$ in $\mathrm{COS}$ cells.}

Monolayer cultivation of COS-7 cells was performed as described (Nennstiel 1998). For transfection, $2 \mu \mathrm{g}$ of plasmid DNA (SeqTag vector containing $C f-9$; Invitrogen, Groningen, The Netherlands) were added to $1.6 \times 10^{6} \mathrm{COS}-7$ cells. Electroporation $(250 \mathrm{~V}, 500 \mu \mathrm{Fd})$ was performed as described (Nennstiel 1998). Electroporated cells were transferred to petri dishes containing Dulbecco minimal essential medium-fetal calf serum (GIBCO-BRL, Karlsruhe, Germany). After 3 days, transfected cells were collected for preparation of microsomal membranes (see below) and AVR9 binding assays. Cotransfection with GFP (2 $\mu \mathrm{g}$ of pCDM8-GFP) (Sheen et al. 1995) was performed to monitor transfection of COS-7 cells.
For monitoring production of Cf-9 protein in COS-7 cells, cells were fixed in $4 \%$ paraformaldehyde and, after blocking unspecific binding sites (10\% goat serum, 3\% bovine serum albumin [BSA]), cells were overlaid with a 1:2,500 dilution of Cf-9 antibodies. These polyclonal antibodies were raised in rabbit against the extracellular domain of Cf-9 that had been produced in Escherichia coli. After incubating cell layers with a 1:2,500 dilution of the fluorescent dye Alexa 546 coupled to goat anti-rabbit immunoglobulin $\mathrm{G}$ (IgG), localization of Cf-9 was visualized by confocal laser microscopy.

\section{Preparation of microsomal membranes from COS cells.}

Transfected COS-7 cells were sonicated, and cell debris was removed by low-speed centrifugation $(1,000 \times g)$. The supernatant was subjected to ultracentrifugation $(100,000 \times$ $g$ ), and the resulting pellet was resuspended in binding buffer (10 mM K-phosphate, $\mathrm{pH} 6.0 ; 0.1 \% \mathrm{BSA}$ ) and used in ligand binding assays without further treatment. Detergent solubilization of microsomal membranes from $C f$-9-transgenic COS-7 cells was carried out as described (Nennstiel 1998).

\section{AVR9 binding assays with Cf-9 producing COS cells.}

Ligand binding assays were performed according to Kooman-Gersmann et al. (1996). If not stated otherwise, transfected COS-7 cells were resuspended in binding buffer to a final concentration of $2.5 \times 10^{6}$ cells per ml. Cells $(100 \mu \mathrm{l})$ were preincubated for $20 \mathrm{~min}$ at $37^{\circ} \mathrm{C}$, and binding was initiated by the addition of $10 \mu \mathrm{l}$ of ${ }^{125} \mathrm{I}$-AVR $9(2,200 \mathrm{Ci}$ per $\mathrm{mmol}$ ) to a final concentration of $200 \mathrm{mM}$. Nonspecific binding was determined in the presence of a 1,000-fold excess of unlabeled AVR9. After incubation $\left(3 \mathrm{~h}\right.$ at $37^{\circ} \mathrm{C}$, with occasional shaking), cells were harvested by filtration on $\mathrm{GF} / \mathrm{F}$ filters (Whatman, Kent U.K.). Filter-bound radioactivity was determined by crystal scintillation with a Wallac 1470 Wizard $\gamma$-counter (PerkinElmer Life Sciences, Gaithersburg, MA, U.S.A.).

AVR9 binding assays with microsomal membranes prepared from transfected COS-7 cells were carried out essentially as described above for intact cells. Microsomal membrane protein $(100 \mu \mathrm{g})$ were used in standard binding assays. In AVR9 binding assays with detergent-solubilized mem-

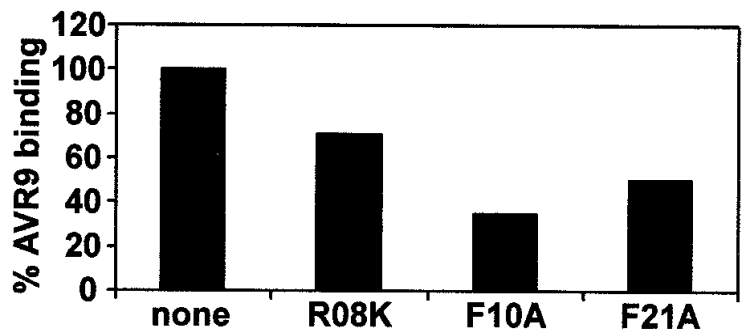

Fig. 9. Surface-enhanced laser desorption and ionization analysis of binding between AVR9 and immobilized c-myc:Cf-9. Immunoprecipitated proteins from microsomal membranes from $c$-myc:Cf-9-transgenic tobacco line 9161 (Fig. 7) were coupled to a protein G-coated chip, which was subsequently incubated with AVR9 protein. After several washing steps (see text for details), the initial AVR9 binding value was determined. Subsequently, the chip was incubated with AVR9 mutants having higher $(\mathrm{R} 8 \mathrm{~K})$ or lower (F10A) necrosis-inducing activity than wild-type AVR9 or no necrosis-inducing activity (F21A). Afterward, the AVR9 binding value was again determined. The amount of AVR9 binding detected is expressed as a percentage of the initial AVR9 binding. 
branes, proteins were collected on Whatman GF/F filters pretreated with $0.5 \%$ polyethylene-imine for $1 \mathrm{~h}$.

\section{Construction of recombinant baculovirus containing Cf-9.}

The complete $C f-9$ cDNA was cloned in pFastBac1 (GIBCO-BRL, Breda, The Netherlands), generating pFB1-Cf9. Additionally, pFB1-Cf- $9^{\mathrm{H}}$ coding for $\mathrm{Cf}-9^{\mathrm{H}}$ protein, which lacks the predicted membrane anchor (Fig. 1) and contains a C-terminal His $_{6}$-tag, was constructed. The generated plasmids were used to obtain recombinant baculovirus via the Bac-toBac Expression System (GIBCO-BRL) according to the manufacturer's protocol.

\section{Insect cells and baculovirus infection.}

Sf21 insect cells were cultured, as described (King and Possee 1992), in Grace's medium (GIBCO-BRL) supplemented with $10 \%$ fetal bovine serum (GIBCO-BRL) in monolayers at $27^{\circ} \mathrm{C}$. For Cf-9 protein production, virus inoculum was added to the cells with a multiplicity of infection of 10 plaque-forming units per cell. After $1 \mathrm{~h}$ at $27^{\circ} \mathrm{C}$, the inoculum was replaced by Grace's medium supplemented with $10 \%$ fetal bovine serum or with SF900 II serum-free medium (GIBCO-BRL) to allow immunological analysis of the culture medium for the presence of the $\mathrm{Cf}-9^{\mathrm{H}}$ protein. To study Nglycosylation, tunicamycin (Kelly and Lescott 1983) was added to a final concentration of $10 \mu \mathrm{g}$ per ml, immediately after replacement of the inoculum by culture medium. Cells were harvested $72 \mathrm{~h}$ after infection and washed in phosphate buffered saline (PBS) prior to further manipulations.

\section{SDS-PAGE and Western blot analysis of $\mathrm{Cf}-9$ produced by insect cells.}

Insect cells were resuspended in approximately $100 \mu \mathrm{l}$ of SDS loading buffer per $10^{6}$ cells. Culture medium was freezedried and resuspended in SDS loading buffer to $1 / 10$ of the original volume. After heating for $5 \mathrm{~min}$ at $100^{\circ} \mathrm{C}$, proteins present in $10 \mu \mathrm{l}$ of the various samples in SDS loading buffer were separated on 7.5\% SDS-polyacrylamide gels and visualized with Coomassie brilliant blue or transferred to nitrocellulose membrane by electroblotting. The blots were incubated with the Cf-9 antibodies, which also were employed to detect Cf-9 protein in COS cells at a 1:5,000 dilution. Antigenantibody complexes were visualized with alkaline phosphatase-conjugated goat anti-rabbit IgG under standard conditions. For N-terminal sequencing, purified protein was separated by SDS-PAGE and blotted onto polyvinylidene difluoride according to Bauw et al. (1987). After Amido black staining, the band of interest was excised and sequence analysis of the protein was performed by Sequentiecentrum Utrecht (Utrecht, The Netherlands).

\section{Protein purification from insect cells.}

To obtain pure $\mathrm{Cf}-9^{\mathrm{H}}$ protein, cells were resuspended in guanidinium lysis buffer and loaded on an Xpress System His $_{6}$-affinity column (Invitrogen). The column was washed and eluted under denaturing conditions in the presence of $8 \mathrm{M}$ urea, according to the protocol provided by the manufacturer.

\section{Preparation of membrane-enriched fractions from insect cells.}

Membrane-enriched fractions from insect cells were prepared based on the procedure of Tate and Blakely (1994) with the following modifications. The procedure was started by suspending the virus-infected insect cells in 1:20 diluted PBB (120 mM NaCl; $5 \mathrm{mM} \mathrm{KCl} ; 50 \mathrm{mM}$ Hepes-NaOH, pH 7.4). The suspension was homogenized by sonication for $20 \mathrm{~min}$ at $4^{\circ} \mathrm{C}$. All steps were performed in the presence of $1 \mathrm{mM}$ of the protease inhibitor phenylmethylsulphonyl fluoride. After centrifugation $(12,000 \times g)$, the final pellet was resuspended in MB3 buffer (250 mM sucrose; $10 \mathrm{mM}$ Tris $\mathrm{HCl}, \mathrm{pH} 7.5)$ to a protein concentration of 1 to $10 \mathrm{mg}$ per $\mathrm{ml}$ and stored at $-80^{\circ} \mathrm{C}$.

\section{Binding studies and native dot blots with Cf-9 producing insect cells.}

Binding studies were performed according to KoomanGersmann et al. (1996). For each assay, 15 to $30 \mu \mathrm{g}$ of protein present in membrane-enriched fractions or in complete cells was used. The amount of glycosylated Cf-9 protein present in these fractions was estimated from a Coomassie brilliant bluestained gel. Binding studies were performed in binding buffer (25 mM phosphate buffer, $\mathrm{pH} 6.0 ; 250 \mathrm{mM}$ sucrose), containing $100 \mathrm{pM}{ }^{125} \mathrm{I}$-AVR9, either at $37^{\circ} \mathrm{C}$ or room temperature. Nonspecific binding was determined in the presence of a 1,000-fold excess of unlabeled AVR9. In the assays performed at room temperature, binding conditions were varied in $\mathrm{pH}$ valves $(\mathrm{pH} 4,5,6,7,8$, or 9) and salt concentrations $(0,100$, or $500 \mathrm{mM} \mathrm{NaCl}$ ). GF6 glass fiber filters (Schleicher \& Schuell, Einbeck, Germany) were preincubated with polyethylamine and washed with the corresponding binding buffer before application of the samples.

For dot-blot experiments, a suspension was made of $2 \times 10^{6}$ insect cells per $\mathrm{ml}$ of binding buffer. To disrupt the cells, the suspension was transferred twice from liquid nitrogen to a $42^{\circ} \mathrm{C}$ water bath and sonicated for $2 \mathrm{~min}$ at $4^{\circ} \mathrm{C}$. Ten microliters of the resulting homogenate was spotted onto nitrocellulose. As a positive control, $31 \mu \mathrm{g}$ of protein of a microsomal fraction of leaves from Lycopersicon esculentum cv. Moneymaker tomato plants harboring $C f-9$ (MM-Cf9) (KoomanGersmann et al. 1996) was spotted. Blots were blocked in binding buffer containing $1 \%$ BSA. After blocking, blots were incubated for $2 \mathrm{~h}$ at $37^{\circ} \mathrm{C}$ in $5 \mathrm{ml}$ of binding buffer containing $1 \%$ BSA and $100 \mathrm{pM}{ }^{125} \mathrm{I}-\mathrm{AVR} 9$. Nonspecific binding was determined in the presence of a 1,000-fold excess of unlabeled AVR9. Blots were subsequently washed for $2 \mathrm{~h}$ at $37^{\circ} \mathrm{C}$ in 5 $\mathrm{ml}$ of binding buffer, and X-Omat AR film (Kodak, Rochester, NY, U.S.A.) was exposed to the blot at $-80^{\circ} \mathrm{C}$ in the presence of an intensifying screen.

\section{Production of Cf-9 by tobacco and preparation of membrane protein extracts.}

The transgenic tobacco line 9161 and corresponding suspension cultures producing Cf-9 with a triple c-myc-tag in the $\mathrm{G}$ domain (c-myc:Cf-9) were generated as described previously (Piedras et al. 2000). The recipient plant, Petite Havana, and the 9161 line were grown in Levington's M3 compost in the greenhouse. Suspension cultures of these lines were subcultured at 2-week intervals in Murashige and Skoog medium (Murashige and Skoog 1962), pH 5.7, supplemented with 3\% sucrose, B5 vitamins, $1 \mathrm{mg}$ of 2,4-dichlorophenoxyacetic acid per $\mathrm{ml}$, and $0.1 \mathrm{mg}$ of kinetin per $\mathrm{ml}$.

Leaf or cell samples were ground in liquid nitrogen, thawed in 2 vol of extraction buffer $(50 \mathrm{mM}$ sodium phosphate buffer, 
$\mathrm{pH}$ 7.5; $50 \mathrm{mM} \mathrm{NaCl} ; 1 \mathrm{mM}$ 4-[2-aminoethyl]-benzenesulfonyl fluoride [Pefabloc; Roche Diagnostics, Mannheim, Germany]), filtered through two layers of Miracloth, and centrifuged at $1,000 \times g$ for $10 \mathrm{~min}$ at $4^{\circ} \mathrm{C}$. The supernatant was subsequently ultracentrifuged at $100,000 \times g$ for $1 \mathrm{~h}$ at $4^{\circ} \mathrm{C}$, and the microsomal membranes in the pellet were solubilized in solubilization buffer (extraction buffer supplemented with $0.1 \%$ [octylphenoxy]-polyethoxyethanol [Nonidet P-40]) and ultracentrifuged at $100,000 \times g$ for $1 \mathrm{~h}$ at $4^{\circ} \mathrm{C}$. The supernatant was aliquotted and stored at $-70^{\circ} \mathrm{C}$. The protein concentration was determined with the BCA protein assay kit (Pierce, Chester, U.K.) with BSA as a standard.

\section{SPR experiments with $\mathrm{Cf}-9$ produced in tobacco.}

The BIAcore $\mathrm{X}$ system for performing SPR experiments was purchased from Pharmacia Biosensor (Uppsala, Sweden). Ten microliters of $50 \mathrm{nM}$ biotinylated AVR9 (Van den Hooven et al. 1999) was immobilized onto streptavidin-coated sensor chips SA (Biosense, Milan, Italy) at a flow rate of $5 \mu$ per min at $25^{\circ} \mathrm{C}$. Increase in the signal after immobilization was 500 resonance units. Total microsomal proteins (see above) from Petite Havana or the 9161 line expressing $c-m y c: C f-9$ were diluted in $20 \mathrm{mM}$ sodium phosphate $(\mathrm{pH} 6.0)$ or $20 \mathrm{mM}$ HEPES ( $\mathrm{pH} 7.3$ ), with or without $100 \mathrm{mM} \mathrm{NaCl}$. All buffers used contained $0.005 \%$ ( vol/vol) surfactant P20 (Biosense). Of these solutions, $80 \mu \mathrm{l}$ was injected into the flow cell and passed over the peptide surface at a flow rate of $20 \mu \mathrm{l}$ per min. Binding was monitored as a mass change in the vicinity of the sensor surface, reflecting the progress of the interaction. Response, expressed in resonance units, is reported as the difference between the signal obtained from the flow cell with immobilized AVR9 and a second flow cell without AVR9 attached. Each association-dissociation cycle was followed by a regeneration phase, during which the flow cell was flushed with $20 \mu \mathrm{l}$ of HBS buffer (10 mM HEPES, pH 7.4; $150 \mathrm{mM}$ $\mathrm{NaCl} ; 0.005 \%$ [vol/vol] surfactant P20 in distilled water) to remove bound proteins.

\section{Immunoprecipitation and immunoblotting of protein extracts from tobacco.}

Prior to immunoprecipitation, the aliquots of either leaf- or cell-solubilized microsomes were thawed and ultracentrifuged at $100,000 \times g$ for $30 \mathrm{~min}$ at $4^{\circ} \mathrm{C}$. From the supernatant, a volume containing 250 to $500 \mu \mathrm{g}$ of protein was precleared in a final volume of $500 \mu \mathrm{l}$ of solubilization buffer (see above) for $1 \mathrm{~h}$ at $4{ }^{\circ} \mathrm{C}$ in the presence of $5 \%(\mathrm{vol} / \mathrm{vol})$ protein $\mathrm{G}$ coupled to beads. The mixture was centrifuged, and the supernatant was incubated with c-myc monoclonal antibodies (Santa Cruz Biotechnology, Santa Cruz, CA, U.S.A.) at a final dilution of 1:50. After $3 \mathrm{~h}$ at $4^{\circ} \mathrm{C}$, the immunocomplexes were either used for SELDI experiments (see below) or Western blotting. In the latter case, after incubation with $5 \%$ (vol $/ \mathrm{vol})$ protein $\mathrm{G}$ coupled to beads for $1 \mathrm{~h}$ at $4^{\circ} \mathrm{C}$, the precipitate was collected by centrifugation, washed three times with solubilization buffer, and subsequently resuspended in SDS-sample buffer.

Precipitated proteins were separated on a 7.5\% SDS gel and transferred onto nitrocellulose (Amersham Pharmacia Biotech, Little Chalfont, U.K.) by wet electroblotting with the Mini-Protean II system (Bio-Rad, Hemel Hempstead, U.K.). The blots were incubated with c-myc polyclonal anti- bodies at a final dilution of 1:2,000 for $1 \mathrm{~h}$ and antigenantibody complexes were visualized with alkaline phosphatase-conjugated goat anti-rabbit IgG under standard conditions.

\section{SELDI experiments with Cf-9 produced in tobacco.}

SELDI assays were performed with the Ciphergen SELDI system (Ciphergen Biosystems, Palo Alto, CA, U.S.A.). Binding experiments were carried out with preactivated surface chips. Preactivation of the chips was carried out following the manufacturer's recommendations. All incubations were performed in a humidity chamber at room temperature. One microliter of protein $\mathrm{G}(0.8 \mathrm{mg}$ per $\mathrm{ml}$ in PBS buffer, $\mathrm{pH} \mathrm{7.3)}$ and $1 \mu \mathrm{l}$ of acetonitrile were spotted on every slot. Covalent linking of protein $\mathrm{G}$ to the chip was carried out for $1 \mathrm{~h}$. After removing excess protein $G$, residual sites on each slot were blocked for $20 \mathrm{~min}$ with $4 \mu \mathrm{l}$ of $1 \mathrm{M}$ ethanolamine in PBS, $\mathrm{pH}$ 7.2. The chip was first washed with buffer A $(20 \mathrm{mM}$ sodium phosphate buffer, $\mathrm{pH} 7.0 ; 500 \mathrm{mM} \mathrm{NaCl} ; 0.1 \%$ Nonidet P-40) for $5 \mathrm{~min}$ and then with buffer $\mathrm{B}(20 \mathrm{mM}$ sodium phosphate buffer, $\mathrm{pH} 7.0 ; 150 \mathrm{mM} \mathrm{NaCl} ; 0.1 \%$ Nonidet P-40) for $5 \mathrm{~min}$. Immunoprecipitated complexes formed between the c-myc monoclonal antibodies and proteins in the solubilized microsomal fractions (see above) were coupled to the protein Gcoated chip for $1 \mathrm{~h}$ and washed in four steps: 5 min with buffer B, 1 min with buffer A, 5 min with buffer B, and 5 min with $20 \mathrm{mM}$ sodium phosphate (pH 7.0). Subsequently, $1 \mu \mathrm{l}$ of a solution of $10 \mu \mathrm{M}$ AVR9 peptide in binding buffer $(20 \mathrm{mM}$ sodium phosphate, $\mathrm{pH} 6.0 ; 0.1 \%$ Nonidet P-40) was spotted and allowed to incubate for $1 \mathrm{~h}$. Afterward, the chip was washed three times with washing buffer (20 mM sodium phosphate, $\mathrm{pH}$ 6.0; $500 \mathrm{mM} \mathrm{NaCl} ; 0.1 \%$ Nonidet P-40), once with $10 \mathrm{mM}$ HEPES buffer $(\mathrm{pH} 7.0)$, and then dried. For competition experiments, the chip was treated similarly. After incubation with AVR9 and subsequent washing steps, however, a 100-fold excess of a competitor peptide was added. After a 1-h incubation, the chip was washed as described above. Finally, $0.5 \mu \mathrm{l}$ of matrix (5 $\mathrm{mg}$ of $\alpha$-cyano-2'hydroxycinammic acid per $\mathrm{ml}$ in $30 \%$ acetonitrile and $0.1 \%$ trifluoroacetic acid) were added to each slot. For the estimation of AVR9-binding values, the adrenocorticotropic hormone (ACTH) was used as an internal standard. The ratio between the ACTH peak and AVR9 peak was calculated in all cases.

\section{ACKNOWLEDGMENTS}

We thank M. Usmany (Laboratory of Virology, Wageningen, The Netherlands) for her help with the baculovirus expression system and A. Romanski (Institute of Plant Biochemistry, Halle/Saale, Germany) for maintenance and transformation of COS cells. J. Sheen (Massachusetts General Hospital, Boston, MD, USA) is acknowledged for providing the pUC8/GFP vector. R. Luderer and R. van der Hoorn are supported by a grant from the Dutch Foundation for Earth and Life Sciences (ALW), projects SLW 805-18.231 and SLW 805-33.231, respectively. H. van den Hooven was supported by EC BIOTECH grant BIO4-CT96-0515.

\section{LITERATURE CITED}

Bauw, G., De Loose, M., Inzé, D., Van Montagu, M., and Vandekerckhove, J. 1987. Alterations in the phenotype of plant cells studied by NH2-terminal amino acid-sequence analysis of proteins electroblotted from two-dimensional gel-separated total extracts. Proc. Natl. Acad. Sci. USA 84:4806-4810. 
Benghezal, M., Wasteneys, G. O., and Jones, D. A. 2000. The C-terminal dilysine motif confers endoplasmic reticulum localization to type I membrane proteins in plants. Plant Cell 12:1179-1201.

Davies, H., Lomas, L., and Austen, B. 1999. Profiling of amyloid beta peptide variants using SELDI ProteinChip (R) arrays. Biotechniques 27:1258-1261.

Dixon, M. S., Jones, D. A., Keddie, J. S., Thomas, C. M., Harrison, K., and Jones, J. D. G. 1996. The tomato $C f$-2 disease resistance locus comprises two functional genes encoding leucine-rich repeat proteins. Cell 84:451-459.

Fivash, M., Towler, E. M., and Fisher, R. J. 1998. BIAcore for macromolecular interaction. Curr. Opin. Biotechnol. 9:97-101.

Flor, H. H. 1942. Inheritance of pathogenicity in Melampsora lini. Phytopathology 32:653-669.

Greenfield, C., Patel, G., Clark, S., Jones, N., and Waterfield, M. D. 1988. Expression of the human EGF receptor with ligand-stimulatable kinase activity in insect cells using a baculovirus vector. EMBO J. 7:139-146.

Hammond-Kosack, K. E., Tang, S. J., Harrison, K., and Jones, J. D. G. 1998. The tomato $C f-9$ disease resistance gene functions in tobacco and potato to confer responsiveness to the fungal avirulence gene product Avr9. Plant Cell 10:1251-1266.

Hjelmeland, L. M. 1990. Solubilization of native membrane proteins. Methods Enzymol. 182:253-264.

Hutchens, T. W., and Yip, T. T. 1993. New desorption strategies for the mass spectrometric analysis of macromolecules. Rapid Commun. Mass Spectrom. 7:576-580.

Jia, Y., McAdams, S. A., Bryan, G. T., Hershey, H. P., and Valent, B. 2000. Direct interaction of resistance gene and avirulence gene products confers rice blast resistance. EMBO J. 19:4004-4014.

Jones, D. A., and Jones, J. D. G. 1996. The roles of leucine-rich repeat proteins in plant defences. Adv. Bot. Res. Inc. Adv. Plant Pathol. 24:89-167.

Jones, D. A., Thomas, C. M., Hammond-Kosack, K. E., Balint-Kurti, P. J., and Jones, J. D. G. 1994. Isolation of the tomato $C f-9$ gene for resistance to Cladosporium fulvum by transposon tagging. Science 266:789-793

Joosten, M. H. A. J., and De Wit, P. J. G. M. 1999. The tomatoCladosporium fulvum interaction: A versatile experimental system to study plant-pathogen interactions. Annu. Rev. Phytopathol. 37:335367.

Joosten, M. H. A. J., Cozijnsen, T. J., and De Wit, P. J. G. M. 1994. Host resistance to a fungal tomato pathogen lost by a single base-pair change in an avirulence gene. Nature 367:384-386.

Keen, N. T. 1990. Gene-for-gene complementarity in plant-pathogen interactions. Annu. Rev. Genet. 24:447-463.

Kelly, D. C., and Lescott, T. 1983. Baculovirus replication: Glycosylation of polypeptides synthesized in Trichoplusia ni nuclear polyhedrosis virus-infected cells and the effect of tunicamycin. J. Gen. Virol. 64:1915-1926.

Kieffer, B. L., Befort, K., Gaveriaux Ruff, C., and Hirth, C. G. 1992. The delta-opioid receptor: Isolation of a cDNA by expression cloning and pharmacological characterization. Proc. Natl. Acad. Sci. USA 89:12048-12052. (Erratum. 1994. Proc. Natl. Acad. Sci. USA 91:1193).

King, L. A., and Possee, R. D. 1992. The Baculovirus Expression System: A Laboratory Guide. Chapman and Hall, London.

Kobe, B., and Deisenhofer, J. 1994. The leucine-rich repeat: A versatile binding motif. Trends Biochem. Sci. 19:415-421.

Kooman-Gersmann, M., Honée, G., Bonnema, G., and De Wit, P. J. G. M. 1996. A high-affinity binding site for the Avr9 peptide elicitor of Cladosporium fulvum is present on plasma membranes of tomato and other solanaceous plants. Plant Cell 8:929-938.

Kooman-Gersmann, M., Vogelsang, R., Hoogendijk, E. C. M., and De Wit, P. J. G. M. 1997. Assignment of amino acid residues of the AVR9 peptide of Cladosporium fulvum that determine elicitor activity. Mol. Plant-Microbe Interact. 10:821-829.

Kooman-Gersmann, M., Vogelsang, R., Vossen, P., Van den Hooven, H. W., Mahé, E., Honée, G., and De Wit, P. J. G. M. 1998. Correlation between binding affinity and necrosis-inducing activity of mutant Avr9 peptide elicitors. Plant Physiol. 117:609-618.

Kuwata, H., Yip, T. T., Tomita, M., and Hutchens, T. W. 1998. Direct evidence of the generation in human stomach of an antimicrobial peptide domain (lactoferricin) from ingested lactoferrin. Biochim. Biophys. Acta 1429:129-141.

Laugé, R., and De Wit, P. J. G. M. 1998. Fungal avirulence genes: Structure and possible functions. Fungal Genet. Biol. 24:285-297.

Leckie, F., Mattei, B., Capodicasa, C., Hemmings, A., Nuss, L., Aracri, B., De Lorenzo, G., and Cervone, F. 1999. The specificity of polygalacturonase-inhibiting protein (PGIP): A single amino acid substitution in the solvent-exposed beta-strand/beta-turn region of the leucine-rich repeats (LRRs) confers a new recognition capability. EMBO J. 18:2352-2363.

Leister, R. T., and Katagiri, F. 2000. A resistance gene product of the nucleotide binding site-leucine rich repeats class can form a complex with bacterial avirulence proteins in vivo. Plant J. 22:345-354.

Mathews, L. S., and Vale, W. W. 1991. Expression cloning of an activin receptor, a predicted transmembrane serine kinase. Cell 65:973-982.

Murashige, T., and Skoog, F. 1962. A revised medium for rapid growth and bioassays with tobacco tissue cultures. Physiol. Plant 15:473.

Nennstiel, D. 1998. Mechanismen der nichtwirtsresistenz in Petersilie. Identifizierung un partielle charakterisierung eines rezeptors für einen peptidelicitor aus Phytophthora sojae. PhD thesis. University of Cologne, Cologne, Germany.

Piedras, P., Rivas, S., Dröge, S., Hillmer, S., and Jones, J. D. G. 2000. Functional, c-myc-tagged-Cf-9 resistance gene products are plasmamembrane localized and glycosylated. Plant J. 21:529-536.

Ren, T., Qu, F., and Morris, T. J. 2000. HRT gene function requires interaction between a NAC protein and viral capsid protein to confer resistance to turnip crinkle virus. Plant Cell 12:1917-1925.

Scofield, S. R., Tobias, C. M., Rathjen, J. P., Chang, J. H., Lavelle, D. T., Michelmore, R. W., and Staskawicz, B. J. 1996. Molecular basis of gene-for-gene specificity in bacterial speck disease of tomato. Science 274:2063-2065.

Sessa, G., D'Ascenzo, M., Loh, Y. T., and Martin, G. B. 1998. Biochemical properties of two protein kinases involved in disease resistance signaling in tomato. J. Biol. Chem. 273:15860-15865.

Sheen, J., Hwang, S., Niwa, Y., Kobayashi, H., and Galbraith, D. W. 1995. Green-fluorescent protein as a new vital marker in plant cells. Plant J. 8:777-784.

Tang, X. Y., Frederick, R. D., Zhou, J. M., Halterman, D. A., Jia, Y. L., and Martin, G. B. 1996. Initiation of plant disease resistance by physical interaction of Avrpto and Pto kinase. Science 274:20602063.

Tate, C. G., and Blakely, R. D. 1994. The effect of N-linked glycosylation on activity of the $\mathrm{Na}(+)$ - and $\mathrm{Cl}(-)$-dependent serotonin transporter expressed using recombinant baculovirus in insect cells. J. Biol. Chem. 269:26303-26310.

Van den Ackerveken, G. F. J. M., Van Kan, J. A. L., and De Wit, P. J. G. M. 1992. Molecular analysis of the avirulence gene avr9 of the fungal tomato pathogen Cladosporium fulvum fully supports the gene-forgene hypothesis. Plant J. 2:359-366.

Van den Hooven, H. W., Appelman, A. W., Zey, T., De Wit, P. J. G. M., and Vervoort, J. 1999. Folding and conformational analysis of AVR9 peptide elicitors of the fungal tomato pathogen Cladosporium fulvum. Eur. J. Biochem. 264:9-18.

Van der Biezen, E., and Jones, J. D. G. 1998. Plant disease-resistance proteins and the gene-for-gene concept. Trends Biochem. Sci. 23:454-456.

Van der Hoorn, R. A. L., Laurent, F., Roth, R., and De Wit, P. J. G. M. 2000. Agroinfiltration is a versatile tool that facilitates comparative analysis of Avr $9 / C f$-9-induced and Avr4/Cf-4-induced necrosis. Mol. Plant-Microbe Interact. 13:439-446.

Van der Hoorn, R. A. L., Van der Ploeg, A., De Wit, P. J. G. M., and Joosten, M. H. A. J. 2001. The C-terminal dilysine motif for targeting to the endoplasmic reticulum is not required for Cf-9 function. Mol. Plant-Microbe Interact. 14:412-415.

Van Kan, J. A. L., Van den Ackerveken, G. F. J. M., and De Wit, P. J. G. M. 1991. Cloning and characterization of cDNA of avirulence gene avr 9 of the fungal pathogen Cladosporium fulvum, causal agent of tomato leaf mold. Mol. Plant-Microbe Interact. 4:52-59.

Webb, N. R., Madoulet, C., Tosi, P. F., Broussard, D. R., Sneed, L., Nicolau, C., and Summers, M. D. 1989. Cell-surface expression and purification of human CD4 produced in baculovirus-infected insect cells. Proc. Natl. Acad. Sci. USA 86:7731-7735. 